\title{
POLLINATION OF POLISH RED LIST PLANTS: A PRELIMINARY STATISTICAL SURVEY
}

\author{
Marcin Zych ${ }^{1}$, Andrzej Jakubiec ${ }^{2}$ \\ ${ }^{1}$ University of Warsaw Botanic Garden, Aleje Ujazdowskie 4, 00-478 Warszawa, Poland \\ e-mail: mzych@biol.uw.edu.pl \\ ${ }^{2}$ Department of Informatics, Warsaw University of Life Sciences-SGGW, \\ Nowoursynowska 166, 02-787 Warszawa, Poland
}

Received: 9.11.2007

S u m m a r y

One of the important problems of modern conservation biology is the lack of reliable data on plant pollination systems, especially for taxa threatened with extinction. This paper is an attempt to collect and analyze the available literature data on pollination of Polish red list plants. The Polish red list includes 469 angiosperm taxa, over $53 \%$ of them are insect-pollinated and visited mostly by bees and flies, insects that are also declining in Europe. These numbers however are mainly based on lists of flower visitors and detailed studies of pollination biology or breeding system are available for less than $20 \%$ of the taxa, with further $10 \%$ almost completely unstudied in terms of their life histories. The paper indicates that there is an urgent need to study plant-pollinator relationships in order to better conserve the biodiversity in local and global scales.

Key words: Threatened plants, red book, pollination crisis, biodiversity, plant-pollinator interactions, conservation

\section{INTRODUCTION}

We are increasingly aware that conserving biodiversity means not only conserving particular taxa but conserving the healthy functioning of all parts of world ecosystems, including various interactions among living organisms, e.g. pollination ( $\mathrm{Buchmann}$ and $\mathrm{N}$ a b h a n, 1996; K e a r n s et al. 1998; Th o m p s o n, 2002; W a s e r and M a field, 2006).

Although human understanding and interest in pollination of some plant species may be traced back to ancient times (Proctor et al. 1996; Cresti and Linskens, 1999), the knowledge of the actual mechanisms of pollination biology and ecology is a relatively recent achievement of human science (W a s e $r$ and $\mathrm{M}$ a y fi e ld, 2006). In spite of the explosive development of pollination studies in the last several decades (Fig. 1), there are few plant groups and species which have been thoroughly surveyed, with still a lot of anecdotic information on numerous plants that obscures rather than shows the actual 'state of the art'. This is especially important in case of endangered taxa. If we consider that losing all pollinators may, at the worst, mean losing 90\% of flowering plant species (Was e r and $\mathrm{May}$ fie ld, 2006), the knowledge of plant breeding systems seems one of essential issues in all conservation endeavors involving flowering plants. Unfortunately, our lack of information on the biology and ecology of many plants as well as on the nature of relationships with animal pollinators may cause that even carefully design restoration projects are likely to fail if regeneration of endangered plant populations ceases. This for instance may be due to insect shortage as there is increasing evidence of the decline of pollinators ( $\mathrm{B} \mathrm{u} \mathrm{chmann}$ and $\mathrm{Nabhan}$, 1996; A 11 en-Wardell et al. 1998; Kearns et al. 1998; Biesmeijer et al. 2006; Vamosi et al. 2006).

Recently there have been several attempts to estimate world (e.g. K le in et al. 2007) and Polish crop plants' (Z y c h and J a k u bi e c, 2006) dependence on animal pollinators but the evidence for endangered plant taxa is scarce. To our knowledge, there is no such statistics for the Polish flora, therefore, based on available literature, we attempted to analyze pollination systems of Polish red list plants with the emphasis on key pollinator agents.

\section{MATERIALS AND METHODS}

The Polish flora is composed of approx. 2400 vascular plant species (M i r e k et al. 2002). The recently published Red list of the vascular plants in Poland includes approx. 20\% species of the Polish flora assigned to seven categories: extinct (Ex), extinct in the wild (EW), declining - critically endangered (E), vulnerable 
(V) and rare (R) (Z a r z y c ki and S ze ląg , 2006; authors do not translate the categories according to IUCN standards). We extracted information on pollination of these plants from the available literature and from our own studies. We were especially interested in the nature of pollination systems of Polish red list plants (anemogamy, hydrogamy, zoogamy or autogamy; for simplicity, we treated autogamous and asexual, e.g. apomictic, taxa together and included in this category only obligate autogams, excluding facultatively autogamous plants), and key pollinators. As the length of this paper is limited, the list of the species with the references of the case studies for particular taxa is not included in the text and may be obtained from the authors upon individual request.

\section{RESULTS}

The Polish red list comprises 469 angiosperm taxa: 40 of them are extinct, 1 extinct in the wild, 140 endangered, 182 vulnerable and 106 rare and potentially endangered. The prevailing part of this group, over $53 \%$ (249 taxa), is insect-pollinated (entomogamous). From the remaining plants, 122 taxa are anemogamous (26\%), seven are hydrogamous (1.5\%), and 41 obligatory autogamous or asexual $(9 \%)$. Three species exhibit mixed pollination systems: two of them (Helianthemum rupifragium and Salix lapponum) are ambophilous (windand insect-pollinated) and one (Hydrilla verticillata, Hydrocharitaceae) is reported as hydro- and anemogamous. For over $10 \%$ of the Red list plants (47 taxa), the literature data on pollination is deficient or at least it was unavailable for the authors of the present study (Tab. 1).

The most important pollinating agents of the entomogamous taxa are hymenopterans (mainly wild bees and honey bee); they are responsible (at least partly) for pollinations of over $73 \%$ of these plants. Dipterans constitute the second important group (visits to approx. $33 \%$ of the taxa). Butterflies and moths visit and pollinate approx. $11 \%$ of the Red list plants, beetles 3\%, and less than $1 \%$ is visited and pollinated by other insects

Table 1

The list of 47 plant taxa from the Polish red list for which the literature data on pollination and/or breeding system was unavailable for the authors.

\begin{tabular}{ll}
\hline Family & Taxa \\
\hline Alliaceae & Allium angulosum, Allium carinatum, Allium scorodoprasum, Allium strictum \\
Asteraceae & $\begin{array}{l}\text { Achillea setacea, Achillea stricta, Erigeron hungaricus, Erigeron macrophyllus, } \\
\text { Erigeron uniflorus, Pulicaria vulgaris }\end{array}$ \\
Brassicaceae & Arabis recta \\
Caryophyllaceae & Cerastium dubium, Cerastium pumilum s. str., Sagina maritima, Sagina subulata, \\
& Silene parviflora, Spergula arvensis subsp. maxima, Spergularia media, Spergularia segetalis, \\
Liliaceae & Gagea minima, Ornithogalum collinum, Tofieldia calyculata \\
Linaceae & Radiola linoides \\
Orchidaceae & Dactylorhiza russowii, Epipogium aphyllum, Orchis palustris \\
Polygonaceae & Polygonum oxyspermum \\
Primulaceae & Anagallis foemina \\
Rosaceae & Cotoneaster tomentosus, Potentilla silesiaca, Sorbus graeca \\
Rubiaceae & Asperula tinctoria, Galium cracoviense, Galium harcynicum, Galium sudeticum, \\
Scrophulariaceae & Veronica bellidioides, Veronica praecox, Veronica prostrata \\
Thymeleaceae & Thymelaea passerina \\
Violaceae & Viola alba, Viola elatior, Viola persicifolia, Viola pumila \\
\hline
\end{tabular}




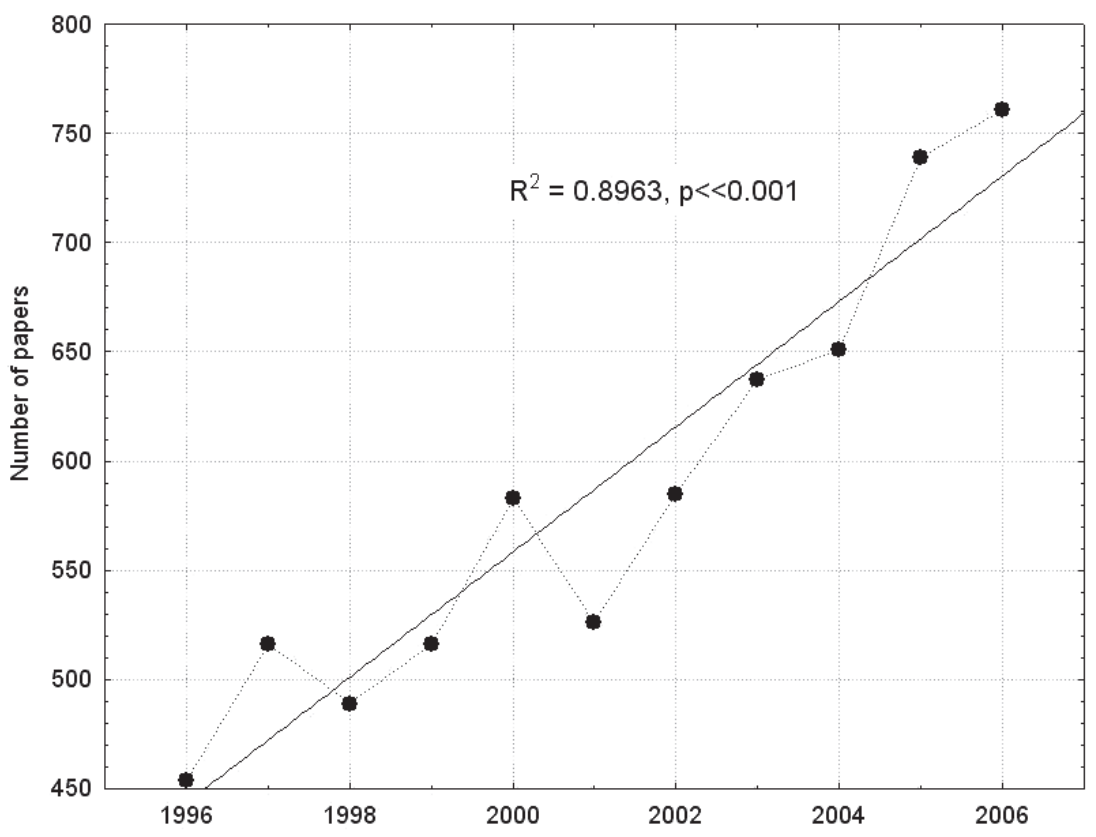

Fig. 1. Titles, keywords and abstracts of papers from ISI Web of Science ${ }^{\bullet}$ database searched for pollination. Dotted line connects points among years and solid line is a regression line.

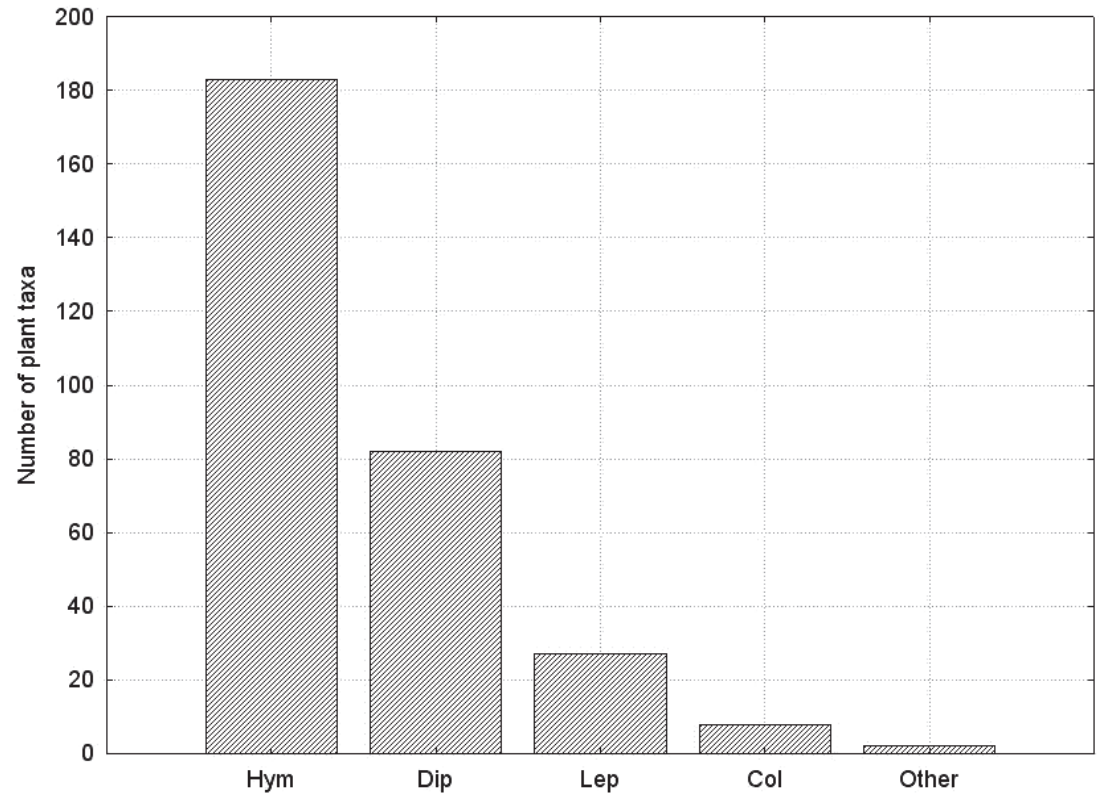

Fig. 2. Key insect pollinators of 249 entomogamous plant taxa from the Polish red list. The number of taxa does not add to 249 as many species are pollinated or visited by, more than one insect group. Hym - bees, Dip - flies, Lep - butterflies and moths, Col - beetles.

(numbers do not add to $100 \%$ as some plants may be pollinated and/or visited by several orders of insects, Fig. 2).

The available literature contains very scarce information on plant breeding systems. We were only able to find data on this aspect of plant biology for approx. $12 \%$ of the surveyed plants, 44 of them are reported to be self-compatible and 13 self-incompatible. 


\section{DISCUSSION}

Numerous plant taxa become endangered and face extinction mainly due to habitat loss, their populations become fragmented and increasingly smaller. In some cases, this trend may be reversed by successful restorations. It is however limited by several environmental and biological factors. For zoogamous plants, one of the reasons of unsuccessful restorations may be the pollination failure that may restrain natural regeneration of endangered plant populations ( $\mathrm{Kwak}$ and $\mathrm{Bekker}$, 2006). This may be due to pollinator shortage and/or the specialized nature of plant-pollinator relationships (Wilc ock and Neiland,2002). The results of the present survey show that at least $54 \%$ of the Polish Red list plants are entomogamous or ambophilous, which means that, at least partially, in their reproduction they are dependent on insect pollinators. Confronting this result with the growing evidence that also pollination systems are under increasing threat from anthropogenic sources, including habitat fragmentation, changes in land use, modern agricultural practices, pesticides and herbicides (A 1len-Wardell et al. 1998; Kearns et al. 1998; Kremen and Ricketts; 2000, Kwak and B ekker, 2006), shows the range of the problem to be faced by conservation biologists.

Most of the entomogamous Polish red list plants are pollinated by bees and flies (Fig. 2). A situation similar to this is found e.g. in the Netherlands ( $\mathrm{K} \mathrm{w} \mathrm{a} \mathrm{k}$ and B ekker, 2006), and the same groups, with bees being the most vulnerable, are also the most threatened in Europe. As reported by Biesmeijer et al. (2006) there were statistically significant declines in bee diversity in $52 \%$ of UK's and $67 \%$ of the Netheralnds' $100 \mathrm{~km}^{2}$ cells which were used by the authors for assessing the pollinator diversity in these two countries. Hoverflies' populations also surveyed in this study seem to be in slightly better conditions (decline in $33 \%$ vs. increase in $25 \%$ of the British cells, and increase in 34\% and decline in $17 \%$ cells of the Dutch cells). This, however, does not compensate for the loss of wild bees. Even in cases where the given plant is pollinated by one key agent, there may be a net gain in resulting seed production form the interactions of various pollinator groups $(\mathrm{We}$ sterkamp and Gottsberger, 2000; Klein et al. 2003; Green le af and K re men, 2006); the diversity of the plant-pollinator interactions enhances also the persistence of plant communities ( $\mathrm{F}$ o n $\mathrm{ta}$ in e et al. 2006). Studies from Europe and other continents suggest that there is a causal relationship between the pollinator and flowering plant decline (B i e s m e i j e r et al. 2006; Vamosi et al. 2006). The species that are most likely to go extinct first are those with the smallest populations and the most dispersed distribution.

When compared to the western Europe, the situation in Poland seems more stable due to higher diversity of agricultural landscapes still present in the country, but still there is an observed decrease in diversity and density of wild bees associated e.g. with xerothermic grassland communities (B a n a z a k, 1992, 1997; B a nas zak et al. 2003), and a decline in bumblebee abundance is observed in many regions of the country (Kosior, 1995; Ruszkowski and B i liński, 1995).

Apart from the importance of insect pollinators to the preservation of endangered plant taxa, the present study shows also gaps in our knowledge. First, over $10 \%$ of the Red list plants (Tab. 1) are completely unstudied in terms of their breeding system or pollination biology (or the information is not easily available), which means we may be missing important clues explaining the causes of their rarity. And second, most of the data on pollination systems available for our work (approx. 80\%) is based on lists of insect visitors (sometimes as old as those of $\mathrm{Knuth}$ (1898-1905), visitation indices or anecdotic observations rather than detailed work on pollinator efficiency. And it is generally agreed that the number of pollinators (or the list of flower visitors) is a poor measure of flower specialization and pollinator importance (W a s e r et al. 1996; J o h n s o n and S te in e r, 2000; P e $11 \mathrm{~m} \mathrm{y} \mathrm{r,} \mathrm{2002).} \mathrm{It}$ has already been demonstrated by many authors (e.g. Herrera, 1987; Fishbein and Venable, 1996, I ve y et al. 2003; Z y c h, 2007) that the key pollinators may constitute only a small portion of the total floral entomofauna.

There are case studies, e.g. for Aconitum lycoctonum (Utelli et al. 1999; Utelli and R o y 2000, 2001), Drosera anglica (M u r z a and D a v i e s, 2005; M u r z a et al. 2006), Gentiana pneumonanthe (P e ta$\mathrm{n}$ i d o u et al. 1995, 2001), Orobanche elatior (O 11 e r to n et al. 2007) or Salix lapponum (Tot land and Sottocornola, 2001), which thoroughly explain pollination biology or breeding system of the studied plants. Unfortunately, they are in minority, the prevailing amount of data being far from complete. This means that we urgently need more studies to obtain a whole picture of the problem.

\section{REFERENCES}

Allen-Wardell G., Bernhardt P., Bitner R., Burquez A., Buchmann S., Cane J., Cox P. A., Dalton V., Feinsinger P., Ingram M., Inouye D., Jones C. E., Kennedy K., Kevan P., Koopowitz H., Medellin R., Medellin-Morales S., Nabhan G. P., Pavlik B., Tepedino V., Torchio P., Walker S., 1998. The potential consequences of pollinator declines on the conservation of biodiversity and stability of food crop yields. Cons. Biol. 12: 8-17.

Banaszak J., 1992. Strategy for conservation of wild bees in an agricultural landscape. Agric. Ecosystems Environ. 40: 179-192. 
Banaszak J., 1997. Local changes in the population of wild bees. I. Changes in the fauna ten years later. Och. Przyr. 54: 119-130.

Banaszak J., Cierzniak T., Ratyńska H., 2003. Local changes in populations of wild bees (Hymenoptera: Apoidea) 20 years later. Pol. J. Entom. 72: 261-282.

Biesmeijer J. C., Roberts S. P. M., Reemer M., Ohlemüller R., Edwards M., Peeters T., Schaffers A.P., Potts S.G., Kleukers R., Thomas C.D., Settele J., Kunin W. E., 2006. Parallel Declines in Pollinators and Insect-Pollinated Plants in Britain and the Netherlands. Science, 313: 351-354.

Buchmann S. L., Nabhan G. P., 1996. The forgotten pollinators. Island Press, Washington DC.

Cresti M., Linskens H. F., 1999. The discovery of sexual reproduction in higher plants. Acta Biol. Cracoviensia, Ser. Bot. 41: 19-29.

Fishbein M., Venable D. L., 1996. Diversity and temporal change in the effective pollinators of Asclepias tuberosa. Ecology, 77: 1061-1073.

Fontaine C., Dajoz I., Meriguet J., Loreau M., 2006. Functional diversity of plant-pollinator interaction webs enhances the persistence of plant communities. PLoS Biol. 4:e1, http://biology.plosjournals.org/perlserv/?request=getdocument\&doi=10.1371\%2Fjournal.pbio.0040001

Greenleaf S.S., Kremen C., 2006. Wild bees enhance honey bees' pollination of hybrid sunflower. Proc. Nat. Acad. Sci. USA 103: 13890-13895.

Herrera C. M., 1987. Components of pollinator "quality": comparative analysis of a diverse insect assemblage. Oikos, 50: 79-90.

Ivey C. T., Martinez P., Wyatt R., 2003. Variation in pollinator effectiveness in swamp milkweed, Asclepias incarnata (Apocynaceae). Am. J. Bot. 90:214-225.

Johnson S. D., Steiner K. E., 2000. Generalization versus specialization in plant pollination systems. Trends Ecol. Evol. 15:140-143.

Kearns C. A., Inouye D. W., Waser N.M., 1998. Endangered mutualism: the conservation of plan-pollinator interactions. Ann. Rev. Ecol. Sys. 29:83-112.

Klein A. M., Steffan-Dewenter I., Tscharntke T., 2003. Fruit set of highland coffee increases with the diversity of pollinating bees. Proc. R. Soc. B, 270: 955-961.

Klein A.-M., Vaissiere B.E., Cane J. H., Steffan-Dewenter I., Cunningham S. A., Kremen C., Tscharntke T., 2007. Importance of pollinators in changing landscapes for world crops. Proc. R. Soc. B, 274: 303-313.

Knuth P., 1898-1905. Handbuch der Blütenbiologie, Vol. I-III. Wilhelm Engelman, Leipizg.

Kosior A., 1995. Changes of the fauna of bumblebees (Bombus Latr.) and cuckoo-bees (Psithyrus Lep.) of selected regions in Southern Poland. [In:] Changes in fauna of wild bees in Europe. Banaszak J. (ed.), Pedagogical Univ., Bydgoszcz.

Kremen C., Ricketts T., 2000. Global perspectives on pollination disruption. Cons. Biol. 14: 1226-1228.

Kwak M. M., Bekker R. M., 2006. Ecology of plant reproduction: extinction risks and restoration perspectives of rare plant species. [In:] Plant-pollinator interactions. From specialization to generalization. Waser N.M., Ollerton J. (eds.), The University of Chicago Press, Chicago.

Mirek Z., Piękoś-Mirkowa H., Zając A., Zając M., Paul W., Ronikier M., Bernacki L., Cieślak E., Głowacki Z., Leda M., Mitka J., Paśnik A., Rostański K., Szeląg Z., Wójcicki J. J., Zalewska-Gałosz J., Zieliński J., Żukowski W., 2002. Flowering plants and pteridiophytes of Poland. A checklist. Biodiv. Pol. 1: 1-442.

Murza G. L., Davis A. R., 2005. Flowering phenology and reproductive biology of Drosera anglica (Droseraceae). Bot. J. Linn. Soc. 147: 417-426.

Murza G. L., Heaver J. R., Davis A. R., 2006. Minor pollinator - prey conflict in the carnivorous plant, Drosera anglica. Plant Ecol. 184: 43-52.

Ollerton J., Stott A., Allnutt E., Shove S., Taylor C., Lamborn E., 2007. Pollination niche overlap between a parasitic plant and its host. Oecologia, 151: 473-485.

Pellmyr O., 2002. Pollination by animals. [In:] Plant-Animal Interaction. An Evolutionary Approach. Herrera C. M., Pellmyr O. (eds) Blackwell, Oxford.

Petanidou T., Den Nijs J.C.M., Oostermeijer J. G. B., E1lis-Adam A. C., 1995. Pollination Ecology and PatchDependent Reproductive Success of the Rare Perennial Gentiana pneumonanthe L. New Phytol. 129: 155-163.

Petanidou T., Ellis-Adam A. C., Den Nijs J. C. M., Oostermeijer J. G. B., 2001. Differential pollination success in the course of individual flower development and flowering time in Gentiana pneumonanthe L. (Gentianaceae). Bot. J. Linn. Soc. 135: 25-33.

Proctor M., Yeo P., Lack A., 1996. Natural History of Pollination. Harper Collins, London.

Ruszkowski A., Biliński M., 1995. The trends of changes in bumblebee fauna in Poland. [In:] Changes in fauna of wild bees in Europe. Banaszak J. (ed.), Pedagogical Univ., Bydgoszcz.

Thompson J. N., 2002. Plant-animal interactions: future directions. [In:] Plant-Animal Interaction. An Evolutionary Approach. Herrera C.M., Pellmyr O. (eds.), Blackwell, Oxford.

Totland Ø., Sottocornola M., 2001. Pollen limitation of reproductive success in two sympatric alpine willows $(\mathrm{Sa}-$ licaceae) with contrasting pollination strategies. Am. J. Bot. 88: 1011-1015.

Utelli A.B; Roy B. A; Baltisberger M., 1999. History can be more important than 'pollination syndrome' in determining the genetic structure of plant populations: the case of Aconitum lycoctonum (Ranunculaceae). Heredity, 82: 574-584

Utelli A. B; Roy B. A., 2000. Pollinator abundance and behavior on Aconitum lycoctonum (Ranunculaceae): an analysis of the quantity and quality components of pollination. Oikos, 89: 461-470.

Utelli A. B; Roy B. A., 2001. Causes and consequences of floral damage in Aconitum lycoctonum at high and low elevations in Switzerland. Oecologia, 127: 266-273. 
Vamosi J. C., Knight T. M., Steets J. A., Mazer S. J., Burd M., Ashman T.-L., 2006. Pollination decays in biodiversity hotspots. Proc. Nat. Acad. Sci. USA 103: 956961.

Waser N. M., Chittka A. L., Price M. V., Williams N. M., Oller ton J., 1996. Generalization in pollination systems, and why it matters. Ecology, 77: 1043-1060.

Waser N. M., Mayfield M. M., 2006. Applications in agriculture and conservation. [In:] Plant-pollinator interactions. From specialization to generalization. Waser N.M., Ollerton J. (eds.), Chicago University Press, Chicago.

Westerkamp C., Gottsberger G., 2000. Diversity pays in crop pollination. Crop Sci. 40:1209-1222.

Wilcock C., Neiland R., 2002. Pollination failure in plants: why it happens and when it matters. Tr. Plant Sc. 7: 270277.

Zarzycki K. and Szeląg Z., 2006. Red list of vascular plants in Poland. [In:] Red list of plants and fungi in Poland. Mirek Z., Zarzycki K., Wojewoda W. Szelag Z. (eds.), Instytut Botaniki im. W. Szafera PAN, Kraków, pp. 9-20.

Zych M., 2007. On flower visitors and true pollinators: The case of protandrous Heracleum sphondylium L. (Apiaceae). Plant Syst. Evol. 263:159-179

Zych M., Jakubiec A., 2006. How much is a bee worth? Economic aspects of pollination of selected crops in Poland. Acta Agrobot. 59:289-299.

\section{Biologia zapylania roślin z Polskiej czerwonej listy: wstępna analiza statystyczna}

\section{Streszczenie}

Jednym z poważniejszych problemów współczesnej ochrony przyrody jest brak informacji o systemach zapylania roślin, zwłaszcza gatunków zagrożonych wyginięciem. Niniejsza praca jest próbą zebrania i przeglądu dostępnych danych literaturowych dotyczących biologii zapylania roślin z Polskiej czerwonej listy. Wyniki analizy wskazuja, iż spośród 469 taksonów roślin okrytonasiennych umieszczonych na liście, 53\% to gatunki owadopylne, zapylane głównie przez pszczołowate i muchówki - owady także zagrożone w skali Europy. Przegląd literatury wskazuje także, że dane te oparte są głównie na opublikowanych listach kwiatowych gości, a dokładne badania biologii zapylania lub systemów reprodukcyjnych są dostępne dla mniej niż $20 \%$ badanych taksonów - dla dalszych $10 \%$ taksonów brakuje jakichkolwiek informacji w tej dziedzinie. Praca wskazuje potrzebę głębszego zbadania zależności rośliny-zapylacze w celu lepszej ochrony ich zróżnicowania w skali lokalnej i globalnej. 